\title{
SEA: Comparing Open Perspectives on Planning Sustainability in Sardinia (Italy) and Torbay (Devon)
}

Commonwealth Journal of Local Governance Issue 10: December 2011- June 2012 http:/lepress.lib.uts.edu.au/ojs/index.php/cjlg

\section{Corrado Zoppi}

University of Cagliari

Via Marengo 2, 09123 Cagliari, Italy

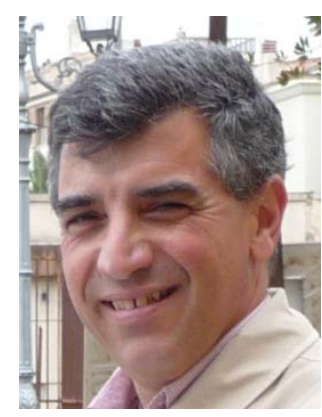

\section{Introduction}

If Strategic Environmental Assessment (SEA) to be effective and fulfil in the spirit of its governing EU Directive 2001/42/EC, cooperative and inclusive attitudes are essential. Cooperation should involve institutions, planning authorities and agencies which are involved in environmental assessment procedures. Inclusion implies favouring and catalysing local communities' participation, that is participation of the public, in the planning/ assessment process.

This paper discusses crucial aspects of SEA through a comparison of two case studies: the SEA of the Torbay Local Transport Plan 2006-2011 (LTPT) published by Torbay Council, and the Masterplan of the Port of the City of Cagliari, 2010 (MPPC) published by the Autorità Portuale di Cagliari in Sardinia, Italy, to provide evidence and lessons of good practice for both the UK and Italy. These include the assessment of:

i. $\quad$ the endogeneity of the SEA process' with respect to the planning process;

ii. the sustainability and participation approaches;

iii. the way available alternative planning options are compared;

iv. the definition of the monitoring process. 
The paper is based on an analysis of the written plans and their SEAs rather than a wider trawl of sources, on the basis that the plan preparation process should be explicit within the plan.

In Italy, implementation of the Directive is based on the Law enacted by decree No. 2006/152, which in the conceptual approach requires careful attention to both the general planning/assessment objectives, which have to be inclusive and incremental, and to participation in the process of key-actors, which has to be effective and easy in terms of its ex-ante and ongoing steps.

In Sardinia (an island of about 24,000 $\mathrm{km}^{2}$ and 1.6 million inhabitants, located west of the Italian mainland near the French island of Corsica), the regional government issued a Guidelines Manual (Regione Autonoma della Sardegna 2010) to ensure that an inclusive and incremental SEA process is implemented, and to set out rigorously defined steps for an authority pursuing an SEA (i.e.: a Sardinian city or province). The aim was to ensure participation of all potentially interested subjects, including public agencies, profit and nonprofit enterprises, social and non-governmental organisations, and citizens, and to speed-up plan approval and adoption, which take place once the SEA preparation process is over. Unfortunately, the application of the Manual is still far from being effective.

All Port Authorities in Italy have a statutory duty to propose a Masterplan which becomes operational once it is approved by the National Council of Public Works. The Masterplan of the Port of Cagliari (MPPC) was approved in $2010^{1}$, and it defines the rules on land use and on the organisation of public services and infrastructure of the area of the Port of Cagliari. The Port Authority of Cagliari rules over a coastal area which extends up to $30 \mathrm{~km}$ along the seashore, including part of the territory of three municipalities (Cagliari, Capoterra and Sarroch). The Port extends along a frontage of $30 \mathrm{~km}$, with a 8-square-kilometer area. The Port is divided into two parts: the historical Port and the Canal Port. The historical Port is for commercial and passengers traffic. Transshipment and RO/RO traffic take place in the Canal Port, located to the Western side of the Port. The Port is well integrated into the historical fabric of Cagliari at a 100-meter distance from the historical centre of the city, close to the main railway station and seven kilometres m away from the airport.

In Torbay, according to the 2006 Environmental Report of the SEA of the Local Transport Plan issued by the Torbay Council (2006; Devon, South-West England),

The goal of sustainable development is to enable people to satisfy their needs and enjoy a better quality of life without compromising the ability of future

\footnotetext{
${ }^{1}$ Statement \#43/2010 of 4 August 2010 by the National Council of the Public Works.
} 
generations to satisfy their needs. Strategic Environmental Assessment assists in promoting sustainable development by integrating sustainability considerations into the plan making process (p. 8).

This approach is consistent with:

i. the United Kingdom's strategy for sustainable development, Building a Better Quality of Life (UK Department of the Environment, Transport and the Regions 2000), which defines four main objectives for the implementation of sustainable development: social progress which recognizes the needs of everyone; effective protection of the environment; prudent use of natural resources; maintenance of high and stable levels of economic growth and employment;

ii. $\quad$ UK Statutory Instrument 2004 No. 1633, "The Environmental Assessment of Plans and Programmes Regulations 2004,” which implement Directive 2001/42/EC of the European Parliament and Council on the assessment of the effects of certain plans and programmes on the environment (the "Directive"), as regards plans and programmes relating solely to any part of England, and

iii. following UK government documents: The Strategic Environmental Assessment: Guidance for Planning Authorities (UK ODPM 2003); A Draft Practical Guide to the Strategic Environmental Assessment Directive (UK ODPM 2004); A Practical Guide to the Strategic Environmental Assessment Directive (UK ODPM 2005); Strategic Environmental Assessment Guidance for Transport Plans and Programmes (UK Department for Transport 2004).

All local transport authorities in England outside London have a statutory duty to produce a Local Transport Plans, and the Torbay Local Transport Plan 2006-2011 (LTPT) set out the vision for integrated transport in the area and priorities for investment and funding to improve roads, public transport, and facilities for walking and cycling in the area over the 5year period. The plan was published in March 2006. The LTPT is implemented by means of four five-year plans (concerning: i. the improvement of accessibility, ii. the improvement of air quality, iii. reducing traffic congestion, iv. improving road safety) and four project schemes to address the most striking road traffic problems (Torbay Council 2006, pp. 79).

The paper is divided into five main sections. After the introduction, section two compares the urban contexts of Torbay and Cagliari, and justifies the choice of these cities for the discussion in this paper. Section three analyses the relationship between SEA and plans (LTPT, MPPC) with respect to endogeneity of SEA, sustainability, and participation. Section four examines the definition of planning alternative options and the monitoring process. Finally the conclusion explores the fundamental differences between the two 
SEAs-Torbay's LTPT and Cagliari's MPPC. In Torbay, since the LTPT ran largely in parallel to its SEA it was very effective in generating a qualitative improvement for the LTPT, while in Cagliari the MPPC was defined before the SEA process started which thus had limited impact on the MPPC.

\section{Cagliari, Sardinia and Torbay, Devon}

Cagliari is the main Sardinian conurbation and a regional capital city, where all the main offices of the regional administration are located (Figure 1). Furthermore, Cagliari is the main city in Cagliari Province, which includes the whole territory of Southern Sardinia. The main Sardinian University, with a student population of about 40,000, and the most important Sardinian Law Court are located in Cagliari. Cagliari has been named as one of the main nine Italian metropolitan areas by Italian Law No. 1990/142. It is therefore a site where a new metropolitan province could be established if the regional administration wishes, and the importance of Cagliari as a key Italian conurbation has been officially recognized at national level.

The Sardinian regional government has primary jurisdiction for land-use and urban planning, according to its constitution, and thus may define Sardinian public planning policies. In fact, the Sardinian region is to some extent autonomous with respect to national planning policies. For all these reasons, the metropolitan area of Cagliari can be considered a significant and well-defined urban environment in which to analyse SEA policies, one which is sufficiently internally developed and integrated, and isolated from external influences as well.

Torbay Council is a unitary authority comprising three towns: Torquay (63,998 inhabitants in 2001), Paignton $(48,251)$, and Brixham $(17,457)$. Torbay is the English Riviera, one of the most important tourist resorts of England (see Figure 2). Torbay is characterized by high density development, like the inner areas of Cagliari. This has perhaps been forced by the area's natural constraints due to its surrounding geography and steep topography, which makes further development within the towns problematic, while the sea forms an absolute barrier to growth to the east. The nature designations which surround the towns also restrict further growth. The economy of Torbay has traditionally been based on tourism, the fishing industry at Brixham and in recent years the high-tech industry, both relatively low-wage economic sectors. There is also concern that these industries are stagnating and there is a marked need to adapt to address this issue.

Despite its peripheral location Torquay and Paignton are well served by rail, although the Service between Newton Abbot and Torquay could be improved. However the road links into Torquay from Exeter in particular are in need of improvement with a bottlenecking for 
traffic particularly at Kingskerswell causing heavy congestion. The proposed South Devon Link Road (to address this congestion) is largely outside the Torbay Unitary Authority Council area and is subject to SEA by Devon County Council.
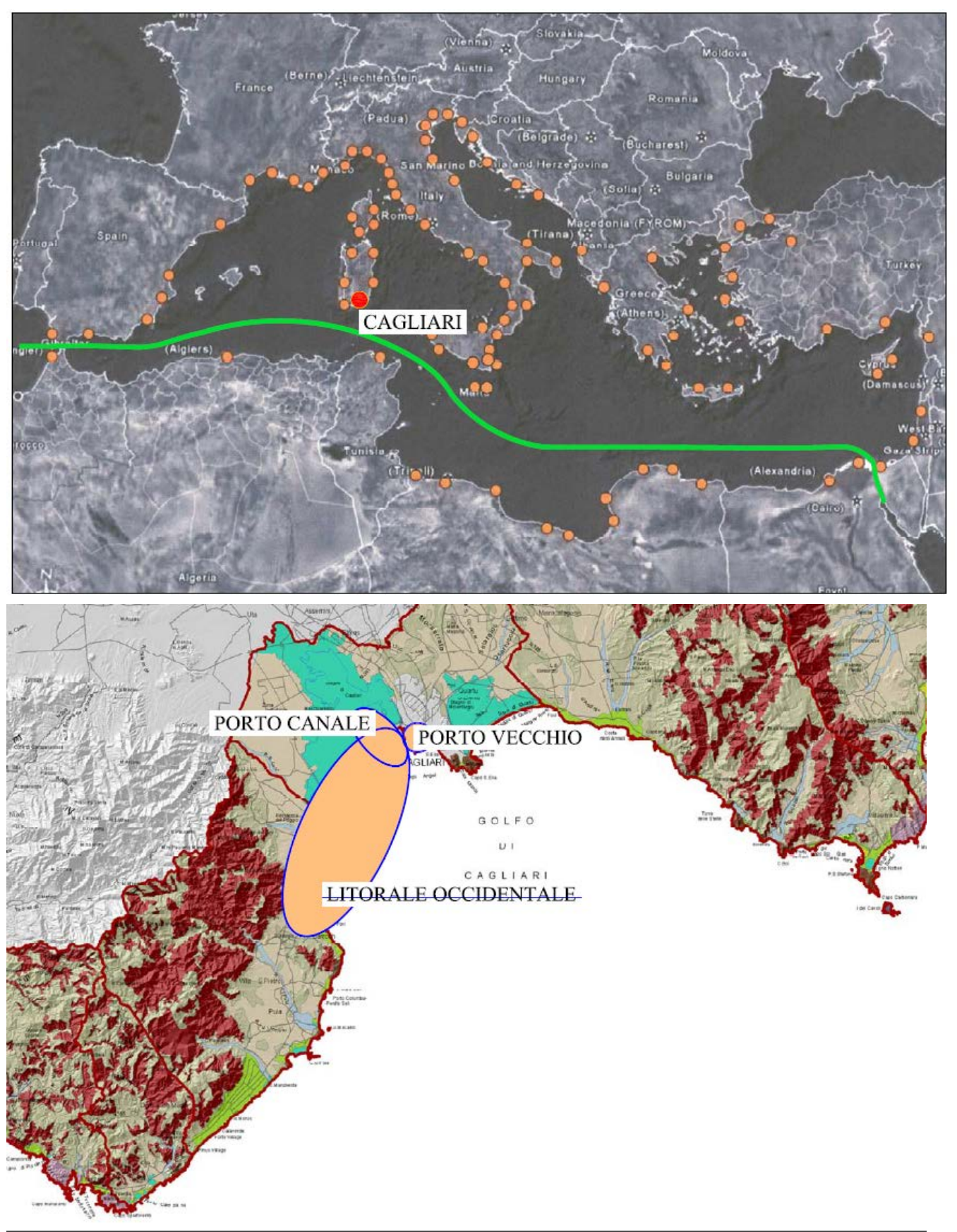

Figure 1. Cagliari, location and the layout of the Port (from the Table 1 of the MPPC, viewed 28 June 2012, <http://www.porto.cagliari.it/images/prp/PRP_TAV_01.pdf >): "Porto Vecchio" is the historical Port; "Porto Canale", the so-called Canal Port, is for transshipment operations; "Litorale Occidentale”, the so-called Western Seashore, is for RO/RO operations and for the location of the ships of the Port Fire Department. 

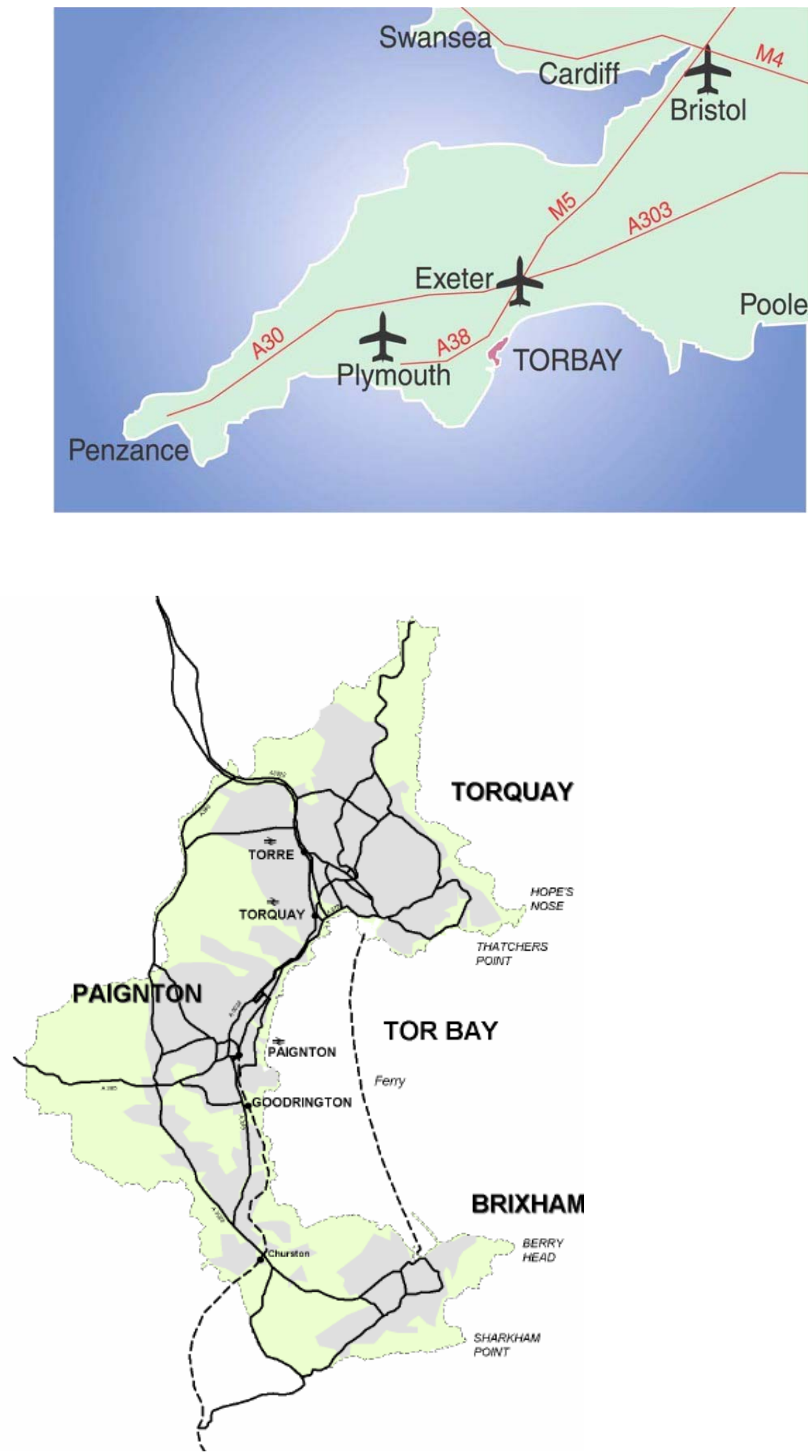

Figure 2. Torbay, location and transport links (Torbay Council 2006, pp. 26; 29). 
The choice of Torbay and Cagliari as case studies is motivated as follows. Cagliari and Torbay are both medium-sized conurbations (both of them have less than two hundred thousand inhabitants). Torbay is governed by a unitary authority, which is in charge of local government and transport. A unitary authority, the Autorità Portuale di Cagliari (the Cagliari Port Authority) rules over the Port area. ${ }^{2}$ Among the tasks of the Authority is the definition and implementation of land-use policy and city planning in the Port area. Cagliari and Torbay are quite peripheral with respect to their national administrations, politically and geographically, but both are quite central with respect to the regional administrations (Devon and Sardinia). Moreover, there is a strong practice of city planning and local services in both conurbations, and consolidated legislation on SEA. For these reasons, an analysis of how SEA was applied in Torbay and Cagliari in order to assess how the two plans related to the organisation of a system of local services could be very useful to give information on similarities and differences between the Italian and English approach to SEA. What we draw from this comparison could be effectively utilized to develop future comparative studies on the implementation of SEA of city planning in England and Italy.

The LTPT and the MPPC are two plans concerning public transport in relatively small metropolitan areas. Both of them rely on public investment for their implementation, and on the involvement of a number of smaller towns, which gives them a supra-municipal character. In both cases, one of the main questions concerning all SEA-related aspects is represented by the relationship between the sea and the mainland. What we consider as the most important issues concerning the SEA process in the rest of this paper have the same urban dimension in the two cases.

If we analyse endogeneity, we will see (in the following section) that in both cases this issue concerns how three municipalities (Torquay, Brixham and Paignton in case of the LTPT; Cagliari, Capoterra and Sarroch in case of the MPPC) implement their planning processes taking (or not taking) account of the parallel SEA processes, and how the governance of the SEA-plan processes develops, in both cases under the supervision of a supra-municipal authority. The sustainability issue is related to very similar environmental components, as it can be seen in the environmental reports of the SEA's of the LTPT (Torbay Council 2006, p. 100 and ff.) and of the MPPC (Autorità Portuale di Cagliari 2010, pp. 338 and ff.), and the participatory aspects are quite similar in terms of quantity of involved people. The monitoring processes and the issue of the definition of the planning alternatives are quite homogeneous as well, since the territorial dimension of the impacts on the environmental

\footnotetext{
${ }^{2}$ Article. 8 of Italian Law No. 1994/84 states that the President of the Port Authority is nominated by the Italian Ministry of Transport and Navigation. This Law concerns the "Redefinition of the legislation on the port areas".
} 
components is almost the same, while defining alternatives implies the projection of new scenarios concerning the metropolitan transportation network in both cases.

\section{Endogeneity, sustainability and participation}

The MPPC goals, and related planning decisions and actions, were defined before the SEA process started. The MPPC had a very long history, which started in the second half of the 1990s and reached its seventeenth revision in 2007 (Autorità Portuale di Cagliari 2007). The SEA process was only activated following the response of the Italian Ministry of the Environment and of the Protection of the Territory and of the Sea to a query by the Port Authority of Cagliari which asked if SEA had to be implemented for the MPPC (Autorità Portuale di Cagliari 2010) ${ }^{3}$. As a consequence, there is no evident connection between the goals of the MPPC and the goals defined by the SEA. The general and specific goals of the SEA are so abstract and generic that they could be consistent with many urban contexts located close a coastal area. The list of these goals includes, for example: considering the opportunity of signing "Green Contracts” which establish ecological criteria with the firms which operate in the Port area; improving and optimizing the irrigation system for the city parks and open spaces in order to prevent waste of water resources; efficient management of solid waste collection; increased use of energy from renewable sources in order to reach $30 \%$ of the total energy consumption within five years; etc. (Autorità Portuale di Cagliari, 2010, pp. 243-244). In other words, the goals in the SEA for the MPPC would be valid for almost any urban plan in Italy or Europe.

The reason for this lack of contextualization is that, since the SEA process was applied to an already-defined plan by the Port Authority, which was the same Authority responsible for the implementation of the SEA process, the Authority did not want to reopen a debate on the MPPC, which had emerged from long and cumbersome discussions between many public and private stakeholders. This case is good example of a general characteristic of the Italian (and Sardinian) SEA processes for regional, city and land-use plans-that the SEA is almost always applied retrospectively to a process which started a long time ago, and so plans are not proceeding together with their environmental assessment. As a result, the SEAs often set out environmental protection goals which are not context-specific, and, as such are not useful in pursuing the main objective of the EU Directive, i.e.: "to provide for a high level of protection of the environment and to contribute to the integration of environmental considerations into the preparation and adoption of plans [...] with a view to promoting sustainable development” (art. 1). Thus, the Italian SEA processes often show lack of

\footnotetext{
${ }^{3}$ This response is registered as No. DSA-2008-0012770 of May 12, 2008, by the Direzione Salvaguardia Ambientale [Direction for Environmental Protection] of the Italian Ministry of the Environment and of the Protection of the Territory and of the Sea.
} 
endogeneity, since they do not integrate local environmental considerations into plan preparation. By doing so, with reference the Directive, these SEA's may fail to promote sustainability, by not integrating environmental considerations into the plan preparation processes.

The SEA of the LTPT suggests a very different attitude towards both endogeneity and sustainability. The five main goals of the LTPT are generated from the SEA process, suggesting that the SEA process is integrated into the plan.

These goals are as follows:

i. improving accessibility;

ii. improving air quality;

iii. decreasing traffic congestion;

iv. increasing road safety;

v. assisting in achieving the aims of the Torbay Community Plan and the delivery of its key initiatives, supporting economic and social development initiatives in Torbay through the provision of good access by all modes, minimizing the environmental impact of transport in Torbay and supporting environmental improvements wherever possible (Torbay Council 2006, pp. 31-32).

Table 1. SEA objectives and LTPT schemes: an example (Torbay Council 2006, p. 65).

\begin{tabular}{|c|c|c|c|c|}
\hline $\begin{array}{l}\text { High level } \\
\text { objective }\end{array}$ & $\begin{array}{l}\text { Detailed question: } \\
\text { does the policy / } \\
\text { proposal... }\end{array}$ & $\begin{array}{l}\text { Explanation of } \\
\text { the detailed } \\
\text { question }\end{array}$ & $\begin{array}{l}\text { What appraisal } \\
\text { will look for }\end{array}$ & $\begin{array}{l}\text { Relevant Plans, } \\
\text { Programmes and } \\
\text { Strategies reviewed }\end{array}$ \\
\hline \multicolumn{5}{|c|}{\begin{tabular}{|l} 
SEA Topic Climatic Factors \\
\end{tabular}} \\
\hline \multirow{2}{*}{$\begin{array}{l}\text { 3. Reduce } \\
\text { vulnerability to the } \\
\text { effects of climate } \\
\text { change e.g. } \\
\text { flooding, disruption } \\
\text { to travel by extreme } \\
\text { weather }\end{array}$} & $\begin{array}{l}\text { 3.1. Minimise the } \\
\text { vulnerability of the } \\
\text { transport } \\
\text { infrastructure to } \\
\text { climate change }\end{array}$ & $\begin{array}{l}\text { Transport } \\
\text { infrastructure } \\
\text { such as bus } \\
\text { routes are } \\
\text { regularly flooded }\end{array}$ & $\begin{array}{l}\text { Schemes within } \\
\text { flood risk areas } \\
\text { Awareness of } \\
\text { flooding issues } \\
\text { within LTP }\end{array}$ & \multirow{2}{*}{$\begin{array}{l}\text { Kyoto Protocol on } \\
\text { Climate Change } 1997 \\
\text { Environment 2010: Our } \\
\text { Future Our Choice (EU } \\
\text { Sixth Action } \\
\text { Programme), } 2001 \\
\text { A sustainable Future for } \\
\text { the South West: The } \\
\text { Regional Sustainable } \\
\text { Development } \\
\text { Framework for the } \\
\text { South West of England, } \\
\text { SWRA, GOSW, 2001 }\end{array}$} \\
\hline & $\begin{array}{l}\text { 3.2. Reduce the } \\
\text { contribution of } \\
\text { transportation to } \\
\text { greenhouse gas } \\
\text { emissions including } \\
\text { the use of low/zero } \\
\text { carbon fuels }\end{array}$ & & $\begin{array}{l}\text { Objective and } \\
\text { schemes to } \\
\text { encourage the } \\
\text { use of low/zero } \\
\text { carbon fuels in } \\
\text { Torbay }\end{array}$ & \\
\hline
\end{tabular}


Why these goals are endogenous with respect to the SEA process is explained if we look at the connections between the objectives related to the SEA topics and the planning schemes, together with the systems of actions which implement the planning goals (Torbay Council 2006, pp. 63-74; Table 1).

Table 1 shows that the high-level objective related to Climatic Factors, defined as Reduce vulnerability to the effects of climate exchange e.g. flooding, disruption to travel by extreme weather, is connected through the appraisal, to (fourth column):

i. $\quad$ LTPT schemes within flood risk areas;

ii. awareness of flooding issues within the LTPT, and

iii. objectives and schemes to encourage the use of low/zero carbon fuels in Torbay.

All these appraisal references consist of actions included in the schemes of the LTPT, summarized later on in the SEA report (Torbay Council 2006, pp. 79-92).

The same procedure is adopted for the rest of the SEA topics, that is, air quality, biodiversity, economic factors, landscape and heritage, population and human health, social inclusiveness, soil, water. Thus, a detailed integration of the SEA objectives into the plan schema and vice versa is evident, where the planning proposals have considered the traits d'union between the LTPT and its SEA.

The endogeneity of the SEA with respect to the LTPT is supported by participatory process through which the SEA was developed. Sustainability relies on incremental and participatory processes, since "by undertaking the SEA it is possible to look at the LTP during its development and examine how it will contribute to the aims of sustainable development. Opportunities to enhance the contribution to sustainable development can be identified, for example, by recognizing aspects where the strategy may compromise sustainable development, and possible amendments to the strategy to resolve any problems” (Torbay Council 2006, p. 16).

Torbay Council recognizes that the participatory process should help seeing and addressing problems in integrating sustainability and local development goals. Many different experts, stakeholders and representatives of public and private bodies were brought together in a large consultation process, run during September and October 2005, whose results are detailed in the SEA report (Torbay Council 2006, pp. 20 and ff.). A general and important characteristic of how these results are incorporated into the SEA process is that every observation, objection, and criticism which comes up in the scoping phase is annotated, but 
also associated to an action which addresses the issue. ${ }^{4}$ It appears that Torbay Council's approach to participation is consistent with by the UK's Statutory Instrument 2004 No. 1633, which implements the EU Directive. ${ }^{5}$

A possible caveat of this SI is that it is not clear how to involve the potential participants who are not part of the public or private organisations which the proceeding administration identified as eligible to be part of the participatory process. In other words, the potential participants who do not belong to these bodies may not see their participation guaranteed by the procedure, which may eventually entail a loss of information and quality in the plan.

In the MPPC, the operational part of the MPPC focuses on determining land uses in the "The Port of Cagliari” area, including planned works on the seabed (excavation and dredging), and identification of future projects subject to environmental impact assessment procedure (Autorità Portuale di Cagliari 2010, pp. 249-273). Neither of these actions or rules is crossreferenced to the (decontextualized) sustainability goals, while all of them are considered connected linked to the MPPC goals.

The MPPC treats participation very differently. Since participation is a formal requirement of the Italian Law enacted by Decree No. 2006/152, which implements the EU Directive in the Italian legislation, the MPPC has to consider participatory moments, which consist mainly of formal correspondence between the Port Authority and several public and private organisations which may have interest in the MPPC, and which may contribute scientific and technical knowledge and to the feasibility of the plan. Unfortunately, the outcome of this formal consultation is that there are notes in the SEA report which certify that the Port

\footnotetext{
${ }^{4}$ This is how the SEA report defines the participatory process (ibid., p. 19): "The SEA Directive requires authorities to identify the public affected or likely to be affected by, or have an interest in a plan, including relevant non-Government organizations. Consultation will take place with the same group identified as consultees for the Scoping Report. Therefore copies of this report will be sent to English Heritage, English Nature, The Environment Agency and The Countryside Agency. Copies will also be sent to members of the Torbay Strategic Partnership, members of the Transport Stakeholders Group, relevant Council Directorates, Councilors, our neighboring Local Authorities, Devon County Council and the South West Regional Assembly. Additionally an electronic version (see link below) will also be available for the public to comment upon and this will be advertised."

${ }^{5}$ SI 2004, No. 1633, 13 (2) states what follows. “As soon as reasonably practicable after the preparation of the relevant documents, the responsible authority shall:

(a) send a copy of those documents to each consultation body;

(b) take such steps as it considers appropriate to bring the preparation of the relevant documents to the attention of the persons who, in the authority's opinion, are affected or likely to be affected by, or have an interest in the decisions involved in the assessment and adoption of the plan or programme concerned, required under the Environmental Assessment of Plans and Programmes Directive ("the public consultees");

(c) inform the public consultees of the address (which may include a website) at which a copy of the relevant documents may be viewed, or from which a copy may be obtained; and

(d) invite the consultation bodies and the public consultees to express their opinion on the relevant documents, specifying the address to which, and the period within which, opinions must be sent.”
} 
Authority got in touch and tried to consult various public and private organisations, but no significant questions raised were addressed in the SEA process. ${ }^{6}$

\section{Alternative planning options and the monitoring process}

According to the LTPT's SEA (Torbay Council 2006, p. 77), the strategic alternatives within the plan were further developed since the publication of the scoping report and subsequent consultation. Even though no alternative local transport plan was identified, changes within the LTPT to the proposed five-year plans for improving air quality, congestion, accessibility and road safety were made although not discussed in the LTPT. These are appraised using a plan/no plan scenario, “where 'no plan' means how the current situation would progress without the five-year plan" (Torbay Council 2006, p. 77). So, the question of alternative planning options is considered quite superficially within the LTPT. The same issue is simply neglected in the MPPC's SEA report, where a paragraph is titled "Sintesi valutativa ed analisi delle alternative" [A synthesis of the assessment process and analysis of the alternative options] (Autorità Portuale di Cagliari 2010, pp. 295-296), but if you read the text there is nothing about possible alternatives.

The lack of a serious alternative planning options analysis may be due to the incomplete endogeneity of the LTPT's SEA, which started a couple of months later than the plan. This timing mismatch might have discouraged the Torbay Council from serious design of planning alternatives, which would have been time-consuming. The total lack of endogeneity was certainly the reason why the Port Authority of Cagliari did not consider alternative options at all.

In contrast, both the LTPT and the MPPC treat the issue of monitoring the plan implementation rigorously. As the LTPT's SEA report states, “Monitoring the environmental outcomes of a plan should make it possible to identify the needs for any future corrective action and to establish how well the plan complies with SEA objectives." (Torbay Council 2006, p. 100) This concept is implemented through the definition of a strict connections between a set of environmental indicators, SEA topics, planning goals and therefore planning schemes. The role of the indicators is to allow the Torbay Council to detect, in real time, if and how changes to the ongoing planning policies should be implemented. Table 2 shows an extract of the monitoring table of the SEA of the LTPT.

\footnotetext{
${ }^{6}$ The participatory process is described very concisely in the SEA report: see Autorità Portuale di Cagliari, 2010, pp. 329-331.
} 
Table 2. An extract of the SEA of the LTPT monitoring table (Torbay Council 2006, p. 101).

\begin{tabular}{|c|c|c|c|c|c|c|}
\hline $\begin{array}{l}\text { Higher } \\
\text { objective }\end{array}$ & Indicator & $\begin{array}{l}\text { Baseline } \\
\text { data (year) }\end{array}$ & $\begin{array}{l}\text { Target } \\
\text { available? } \\
\text { (year) }\end{array}$ & Source & $\begin{array}{l}\text { How often } \\
\text { monitored }\end{array}$ & comments \\
\hline \multirow{2}{*}{$\begin{array}{l}\text { Control air } \\
\text { pollution to a } \\
\text { level which } \\
\text { does not } \\
\text { cause } \\
\text { damage to } \\
\text { natural } \\
\text { systems and } \\
\text { human } \\
\text { health }\end{array}$} & $\begin{array}{l}\text { Journey time } \\
\text { around the } \\
\text { Bay }\end{array}$ & $\begin{array}{l}17.4 \mathrm{mph} \\
\text { (mean) } \\
(2004 / 05)\end{array}$ & $\begin{array}{l}25 \mathrm{mph} \\
(2010 / 11)\end{array}$ & $\begin{array}{l}\text { Council } \\
\text { surveys }\end{array}$ & Annually & $\begin{array}{l}\text { Data available } \\
\text { from Strategic } \\
\text { Transport } \\
\text { Team }\end{array}$ \\
\hline & $\begin{array}{l}\text { Number of } \\
\text { AQMAs (Air } \\
\text { Quality } \\
\text { Management } \\
\text { Areas) }\end{array}$ & $\begin{array}{l}1 \text { AQMA } \\
(2004 / 05)\end{array}$ & $\begin{array}{l}0 \text { AQMA } \\
(2010 / 11)\end{array}$ & $\begin{array}{l}\text { Mandatory } \\
\text { Indicator Air } \\
\text { Quality } \\
\text { Monitoring } \\
\text { data }\end{array}$ & Annually & $\begin{array}{l}\text { Data available } \\
\text { from } \\
\text { Environmental } \\
\text { Health }\end{array}$ \\
\hline
\end{tabular}

The monitoring effort of the MPPC aims at identifying those indicators which may give a good picture of the environmental context of the Port of Cagliari, but it fails to consider the relations between planning strategies and actions, and the health status of the environment (Autorità Portuale di Cagliari 2010, pp. 338 and ff.). So, the monitoring table is quite similar to Table 2, except for column 1. It is hard to understand how the monitoring process of the MPPC could be effective, if the monitoring plan does not state how the environmental status is connected to the planning schemes.

\section{Conclusion}

The question of endogeneity of the SEA process with respect to the plan development process is dealt with very differently in the Italian and English cases. In the former, the plan was almost completely defined when the SEA started, and endogeneity was totally neglected. This enormous contradiction between the EU Directive and its practical implementation in Italy (the Sardinian experience is unfortunately consistent with what happens in the rest of Italy with reference to regional and urban planning processes) is possibly due to the late implementation of the Directive in the Italian legislation ${ }^{7}$. There are several recent plans, e.g.: the regional and city plans of the Region Emilia-Romagna, where the gap is shortened between the plan and the SEA process, and the SEA and plan definition processes can proceed together, at least to some extent. The recently-issued Guidelines Manual of the regional administration of Sardinia (Regione Autonoma della Sardegna 2010) is an important reference point for inclusive, incremental and participatory SEA in the context of Italian planning processes.

\footnotetext{
${ }^{7}$ The chapters of the Italian Law enacted by decree No. 2006/152 which implement the Directive were established in a proper way only in 2008 and 2010 (Law enacted by decree No. 2008/4 and 2010/128).
} 
England implemented the Directive on time (2004), and the question of endogeneity was taken into account properly. The LTPT's SEA bears witness to this, since the SEA process is assumed as a very important reference for the plan definition. It is highly significant, from this point of view, that the SEA report complains that "The main obstacle to conducting this SEA was the late beginning of the SEA process. With hindsight it is easy to see that the SEA should have begun in July 2004 rather than January 2005. The Environmental Report should have gone out for public consultation with the LTP2 in July 2005, rather than in March 2006." (Torbay Council 2006, p. 25) This indicates the extent to which Torbay Council is aware of the importance of endogeneity, since a very short timing mismatch (a few months) is signalled as a negative point. The new version of the LTPT shows an almost perfect correspondence between SEA and plan processes. Endogeneity of the SEA process seems inherent, even though the new LTPT was not in force at the time of writing (Devon County Council and Torbay Council 2010). ${ }^{8}$

With reference to participation, the analysis suggests that the English approach is sitespecific and oriented to incorporate the participants' contributions into planning decisions. The Port Authority of Cagliari seems not to rely on a real improvement of the quality and effectiveness of the plan coming from a participatory process. On the other hand, the issue of the involvement of the public is not addressed even in the LTPT. This issue is fundamental in order to implement sustainability in the SEA and planning process, as the European Commission states in its guidelines (European Commission Environment 2001). Dissemination of information and fairness of the decision processes, which are most likely to be ensured by awareness and participation of the local community in defining and implementing public policies, are certainly important in generating the most socially desirable outcome. The role of the public administration would be instrumental in developing a process of this kind for the futures of the Port of Cagliari and of the transport system of Torbay.

Moreover, the presence of real alternative planning options would make it easier for the public to understand what is at stake. Alternatives must be presented to the local community and public hearings on the outcomes and implications must be held. Tentative rankings of alternatives should be discussed and criteria defined, which should prove more-or-less decisive in determining the rankings. The pros and cons of different alternatives' have to be

\footnotetext{
${ }^{8}$ The new LTPT will be in force between April 2011 and March 2026. It has been studied and will be implemented by a partnership which includes the Devon County Council and the Torbay Council. A detailed description of the plan and SEA process is available on Internet (Devon County Council and Torbay Council 2010).
} 
made as clear as possible, and further consideration and discussion of the main issues must be encouraged, even though they may delay the implementation of the final plan.

Finally, the importance of the monitoring process is not understated in either SEA report. However, Torbay Council is more effective than the Cagliari Port Authority in identifying connections between plan and SEA goals and the health of the environment. It seems unlikely that an effective monitoring process could eventually be developed without awareness of this connection. This seems to be consistent with the fact that Torbay Council indicates that "sustainability monitoring reports will be published as part of the LTP Progress Reports”, while this kind of indication cannot be retrieved in the SEA report of the MPPC. A common characteristic of the two monitoring processes is that there is a significant lack of data, since in both cases there are a number of indicators for which no data are currently available.

The substantial failure of the SEA of the MPPC indicates that endogeneity is fundamental for the SEA to be useful and successful, even though the other aspects should not be neglected in the SEA implementation process.

\section{References}

Autorità Portuale di Cagliari [Cagliari Port Authority] 2010, Piano Regolatore del Porto di Cagliari. Valutazione Ambientale Strategica [Masterplan of the Port of the City of Cagliari. Strategic Environmental Assessment], Autorità Portuale di Cagliari, viewed 28 June 2012, <http:// www.porto.cagliari.it/ index.php?option= com_content\&view= article\&id= 93\&Itemid=112\&lang=it>.

Devon County Council \& Torbay Council 2010, Local Transport Plan. Third Torbay Local Transport Plan, Devon County Council \& Torbay Council, Torquay, viewed 28 June 2012, <http:// www.torbay.gov.uk/index/ transportandstreets/ transportpolicy/ transportplan.htm>.

European Commission Environment 2001, Implementation of Directive 2001/42 on the assessment of the effects of certain plans and programmes on the environment, European Commission Environment, viewed 28 June 2012, <http://ec.europa.eu/environment/eia/pdf/ 030923_sea_guidance.pdf>.

Regione Autonoma della Sardegna [Sardinia Autonomous Region] 2010, Linee Guida per la Valutazione Ambientale Strategica dei Piani Urbanistici Comunali [Guidelines for Strategic Environmental Assessment of City Masterplans], Regione Autonoma della Sardegna, viewed 28 June 2012, <http://www.sardegnaambiente.it/documenti/18_269_20110203150553.pdf >.

Torbay Council 2006, Local Transport Plan 2006-2011. Strategic Environmental Assessment. Environmental Report, Torbay Council Community Services, Torquay, viewed 28 June 2012, $<$ http://www.torbay.gov.uk/ltp-sea-env-report.pdf $>$.

UK Department for Transport 2004, Strategic Environmental Assessment Guidance for Transport Plans and Programmes, UK Department for Transport, London.

UK Department of the Environment, Transport and the Regions 2000, Building a Better Quality of Life, Department of the Environment, Transport and the Regions, London, viewed 28 June 2012, <http://www.bis.gov.uk/files/file13547.pdf>.

UK ODPM (United Kingdom Office of Deputy Prime Minister) 2003, The Strategic Environmental Assessment: Guidance for Planning Authorities, UK ODPM, London. 
UK ODPM 2004, A Draft Practical Guide to the Strategic Environmental Assessment Directive, UK ODPM, London, viewed 28 June 2012, <http://www.communities.gov.uk/ documents/ planningandbuilding/ pdf/ draftpracticalguide.pdf>.

UK ODPM 2005, A Practical Guide to the Strategic Environmental Assessment Directive, UK ODPM, London, viewed 28 June 2012, <http://www.scotland.gov.uk/Resource/Doc/ 921/0018361.pdf>. 